\title{
THE ROLE OF TRENDS IN GUIDING THE DEVELOPMENT OF TOURISM AND HOTEL INDUSTRIES IN THE $21^{\text {sT }}$ CENTURY
}

\author{
J.Ruszkowski *, K. Kotra ** \\ *Silesian School of Economics and Languages \\ Marketing Department \\ **School of Banking in Poznan \\ Campus Faculty in Chorzów - Poland \\ Poznan, Poland
}

\begin{abstract}
New and dominant trends in the world's tourist market are determined by economic factors as well as by the outcomes of recent political changes. This is particularly true about Europe, the largest tourist market throughout the world, which has seen significant developments (e.g. the collapse of the totalitarian Soviet bloc, the democratization of societies in the former communist countries, the formation of the European Union, etc.). The changes have led to the globalization of tourism supply and demand based on the ongoing integration of new countries and entire regions into the international tourist market. The paper aims to highlight the impact that these developments have had on defining tourism development trends in the $21^{\text {st }}$ century, and to demonstrate how tourism products are used to meet customers' motivations, needs and expectations. The first part of the paper discusses the leading trends and their role in guiding the development of world tourism. The final section focuses on the megatrends that have emerged in the $21^{\text {st }}$ century (especially international) tourist industry.

Keywords: tourism and hospitality market, new developments in world tourism, new trends and directions in tourism and leisure industries, UNWTO megatrends by 2020
\end{abstract}

In economic terms, tourism should be regarded as a form of business activity in the high-order services sector. International tourism accounts for a significant portion of international economic exchange.

Tourism also represents an important component of international economic relations. It is inevitably associated with such notions and processes as: geographic mobility of people, transfer of moneys and capital, exchange of goods and services, foreign exchange rates, balance of payments, or international cooperation [1]. Therefore, economic factors largely influence trends in tourism.

To a considerable extent, new trends arising in the tourist services market also relate to recent geopolitical transformations around the world. This is particularly true about Europe, arguably the world's biggest market (e.g. the collapse of the Soviet totalitarian system, democratization across the former communist states, the founding of the European Union, etc.). The changes have led to the globalization of demand and supply in the tourist services market as the market embraces new countries and entire geographic regions [2].

The rapid progress of human civilization that we see in the $21^{\text {st }}$ century is unprecedented in history and produces wonders in science in technology. Scientific research is flourishing, involving e.g. investigation of trends through the acclaimed Globonomic approach based 
on combining and synthesizing whatever information is available. Since 1980, scholars have attained global supremacy in forecasting development trends. Forecasts are employed in management information systems, providing meaningful support for decision making processes, allowing decisions to be grounded on reasonable likelihood rather than relying on intuition and the trial and error method [6]. The paper aims to demonstrate how the knowledge of trends delineating the development of tourism in the $21^{\text {st }}$ century can be capitalized on, how tourists' needs and motivations continue to evolve, and how products are fashioned to meet the customers' changing expectations.

\section{Leading trends and megatrends}

Under tough competition, a company's survival in the market depends on its ability to acquire current information on customers' requirements and preferences. Agencies that can provide the benefits that their customers seek will be among the survivors. A company will only be able to make a success if it is well prepared for the changes that will come and can respond quickly to the need to discard end-of-life products. In his book "Trends 2000", G. Celente treats of "How to Prepare for and Profit from the Changes of the 21st Century" [6]. The studies, including marketing research, sought to explore customers' behaviors with a view to adjusting the supply of tourism products to the structure and level of demand. Werner Wyss, the owner of a marketing research institute from Switzerland, thinks that changes in people's conduct and their decision making habits stem from transformations occurring in the human brain [5].

In Hans von Bergen's opinion, the right brain hemisphere is responsible for collecting and processing information while the left hemisphere combines and links pieces of information together. As a result, the idea of stereoscopic thinking emerges [5]. It is essential to understand the extent to which changes in human thinking are affected by physiological processes and the extent to which they are determined by changes in the models and patterns of consumer behaviors. An important issue facing the new marketing approach is that of identifying the new customer. With the vast dynamics of ongoing transformations, the classical concept of market segmentation based on economic, demographic and societal criteria has long been replaced by the concept of an individual client with diverse requirements, interests and preferences. Attempts to portray the modern man and the modern woman are made with regard to dominant trends as these are consistently examined. Wyss introduced a distinction into leading trends and megatrends. Leading trends were isolated according to some 80 principal attitudes that had been recorded and described over a period of 10 years, while megatrends were said to be shaped by such factors as extraversion, level of activity, sexuality, hedonism, comfortable living and the use of technology. Megatrends are thus characterized by individualism and consumption-oriented behaviors. The author consistently studied changes in the society, using such methods as representative surveys and trend monitoring [5].

Research findings show that a new model of customer and consumer behavior has emerged, marked by a blend of individualism and hedonism. Besides, an increasingly powerful new segment of customers is unfolding who build their lofty expectations toward the super-exclusive products they purchase around the principle "expensive goods for the few". The largest segment is made up of middle class consumers buying average-priced 
products and lower class customers buying the cheapest goods.

Among trends that play a major role in tourism are: the amount of leisure time and the way it is spent; demographic factors including the declining population growth rate and increasing life expectancies resulting in a greater number of pensioners; changing lifestyles; environmentalism; the growth of independent travel (e.g. backpacking), and technology changes in making holiday reservations [3].

While discussing trends one must not fail to mention A. Toffler who predicted the course of changes taking place in today's world: the accelerative thrust, subterranean cities, transience and impermanence, ad-hocracy, cyborgs, overchoice (a.k.a. choice overload), the fractured family, and the future shock along with its psychological implications. Admittedly, in his writings published in the 1970s the celebrated American futurologist foresaw many of the trends shaping our lives in the $21^{\text {st }}$ century [21].

\subsection{The individualism trend and its consequences}

The individualism trend blurs the distinctions between study, work and leisure, as well as the boundaries between school time, working time and leisure time. Individualized, unique forms of relaxation are sought, suited to one's personal lifestyle. Therefore, the number of market segments can be expected to grow and become increasingly diverse. A powerful industrial working class is arising and beginning to look for new ways of spending their free time. People tend to work increasingly harder, longer and more quickly. The leisure industry is growing fast [8]. The most fashionable of extreme sports, such as hydrospeed, canyoning, rafting, dream jumping, bungee jumping, zorbing, kitesurfing, paintball, survival, etc. involve the use of suitable equipment.

Among leisure goods are now included places of worship or e.g. the excitement of driving a Ferrari. Models and patterns observed in the workplace are often transferred to our free time activities. We feel that we must make the most of our leisure time. We want adrenaline and extra energy, and this need defines new directions for the development of tourism. Tourists' interest is attracted by Kamchatka's geysers; safaris in Norway; the waterfalls of Iceland; Alaskan weddings with bears as your best men; or the Valley of Geysers in Kamchatka, regarded as Russia's second greatest wonder, inferior only to Lake Baikal, which only 3000 tourist allowed to visit every year due to environmental constraints (i.e. not to jeopardize its sensitive ecosystem). The area ranks among the seismically most active regions of the world. The volcanic canyon is 4 kilometers long and 2 kilometers wide and contains 20 large and medium sized geysers as well as thermal a lake which consumed about a dozen geysers as it formed in 2007 [7]. Showered by fountains of boiling water, inhabited by bears playing with their young, plagued by hurricanes and swarms of mosquitoes, the Valley has become a genuine magnet for the toughest among tourists.

Even the eruption of Iceland's Eyjafjallajökull volcano turned to be an opportunity for the development of tourism. Advocates of dark visions can spend time on black beaches, relishing the view of the black rocks of Reynisdrangar. Lovers of movie tourism can fly to Hofn and take a boat cruise of the glacier bay where the James Bond picture "Die Another Day" was filmed. In the movie, the bay imitated the Arctic landscape. A variety of swampand-lake routes for canoeists are offered by Alaska. While canoeing through the Glacier Bay, one is accompanied by cetaceans and seals.

Cetaceans are known for their acrobatic leaps, with their 50-tonne bodies thundering 
onto water while their extraordinary, powerful songs are heard within a radius of many miles. Alaska is experiencing an invasion of lone girls who, inspired by the TV series "Men in Trees", come to look for husbands because the gender proportions are promising (13 men to 10 girls). A relationship becomes formal on cutting the couple's names on a tree. Bears hanging around them all the time are fine additions to their wedding photos.

Among dreamers and visionaries there are those who seek attractions at the Earth's bottom, that which is called Antarctica by Werner Herzog. Research bases, towns and settlements, inhabited by several thousand people, teem with life: the greenhouse is looked after by a linguist, the forklift truck is operated by a philosopher, the bus is driven by an economist, and a former film director presents an ice-cream making machine. This is a perfect refuge for humanists disappointed with the realities of their everyday lives who, after many years of intellectual strain, discovered simple but useful jobs and activities [18].

However, these days it is not enough to just visit a place - one is supposed to do something special, preferably something uncommon and extravagant. It has become fashionable to spend holidays with famous travelers and all sorts of celebrities. The USA is definitely among the most exciting tourist destinations. At the end of April, for example, Tornado Alley inaugurates its tornado chasing season, which has recently gained a touristic, and hence commercial, aspect. Tourists purchasing all-inclusive deals are provided with accommodation, transportation, a guide, and a chance to encounter a real tornado. It must seem paradoxical that, while others flee, some people are willing to pay for an opportunity to confront nature's destructive power. Some of these, in the hope of to gaining credit for bravery and impressing their friends and next of kin, showcase their photos on Facebook. Apparently, $21^{\text {st }}$ century people need to do such things. Tornado Alley is situated in the Great Plains; the combination of warm, humid air from the Gulf of Mexico and dry eastern winds from above the Rocky Mountains make this area a perfect breeding place for this dreaded natural disaster [11].

Eccentric and wealthy customers choose to explore the outer space. At the expense of 20 million US dollars, one can not only see the Blue Planet but also garner a global multimillionaire reputation - which matters a lot to some tourists. It was an eccentric visionary, businessman and traveler that created Virgin Galactic and intends to offer tourists sub-orbital flights (more than 100 kilometers above the Earth's surface, with 5 to 10 minutes' experience of weightlessness) at a moderate price of 200,000 US dollars. If Virgin Galactic does send its Space Ship Two on a passenger flight into the space in 2013, it will be the first business enterprise to launch scheduled space flights. Initially, space tourists are supposed to spend about 3 hours in the space. In 2007, the company had already received 60,000 orders, and 500 clients had already bought tickets for the trip of their lifetime [12]. Virgin Galactic was an idea of Sir Richard Branson's; this British millionaire wishes to go into space with his family on Virgin's debut flight.

The leisure industry is thus sure to soon expand its product ranges by offering spaceflight related and complementary products.

\section{Trends in the hotel industry}

The evolving lifestyles of potential customers, income polarization relating to megatrends, and their needs resulting in the pursuit of individualized leisure time activities, 
mobilize the tourism sector to seek new solutions in the hotel industry.

One should be amazed by the scale and momentum of modern architecture and by the stunning technologies it uses. The time is gone when classical proportions would effectively ensure the beauty and harmony of architectural forms and every architect would follow the established rules. Nowadays there are no rules, or they are laid down by designers themselves. As a result, architectures do happen to lack harmony [19].

The tourist industry offers hotel or other accommodation for less affluent customers (e.g. in hostels, mobile homes, tents, campers, etc.) as well as for those very well-todo: in luxury, six- or seven-star hotels. The trends indicate that many customers in all income groups look for originality and novelty, even if their motivations will ry. One of the novelties in the hotel industry is accommodation arranged in a former prison house. A bed \& breakfast inn in Preston, Minnesota, is located in the historic Fillmore County jail. The Four Seasons hotel in Istanbul, Turkey, seated in the former Sultanahmet Jail, has been named "the most beautiful prison in the world". Oxford's Malmaison hotel retains the premises as well as the name of the old jailhouse. Boston, USA, prides on its Liberty Hotel housed in a granite-rock building which used to be the place of detention for the most dangerous criminals [17]. Das Park Hotel in Ottensheim, Austria, (near Linz) represents another interesting idea for a hotel, with rooms built from giant concrete sewage pipe segments, 2 meters in diameter, with the sole pieces of furniture being an undersized bedside lamp and a painting on a wall.

Ice hotels constitute a very attractive architectural form for tourists fond of low temperatures. In Jukkasjärvi, a village in the north of Sweden which his otherwise devoid of any tourist assets, an Icehotel is erected every autumn from clear, transparent ice blocks [9]. This unique hotel captivates lots of ecologically oriented voyagers as well as many of those that will simply wander about looking for distinctive experiences and a chance to show off. Suitable ice must be, because of statics as well as for esthetic reasons, completely transparent and free from any air bubbles, stains or cracks. The construction work takes off at the end of November, but the "building" ice starts to be molded as early as in March. The ice comes from one the cleanest rivers of the world, the Torni, and is indeed as transparent as crystals. When the ice layer is 90 centimeters thick, workmen cut out blocks 1 by 2 meters in size and carry them to a cold store. Windows, ceilings and most details are sculpted from ice, while walls and floors are made of artificial snow. Its architectural design gives it a marvelous, magical shape and air. It is such a pity and every spring the edifice melts into the local lake. The Icehotel has 60 rooms, with ice beds covered with reindeer hides, and hot berry juice is served in fist-sized casks carved in crystal-clear river-water ice. A night at the hotel costs from 400 to 900 US dollars.

China has built a complete ice town, using 100,000 tonnes of ice and a similar amount of snow. The Dutch designer Tord Boontje, inspired by the tales of the Snow Queen and the Wizard, ornamented the interior of a $15^{\text {th }}$ century building in underground Innsbruck with snow hills, frosted trees and icicles to transform it into a thematic winter wonderland. A large patronage delights in icebars that can be found e.g. in Milan (Italy), Tokyo (Japan), London (UK), and Warsaw (Poland). All these products can be also seen as parts of the leisure industry. Another type of extraordinary hotel is the so called Boutique hotel, intended for those who are fed up with standard accommodation. Each such hotel is different, and each 
room in it looks different than the others. Most Boutique hotels are cozy and luxurious, and provide highly personalized, customizable services. Their visitors usually appreciate their intimate character and individual approach to each customer [13].

Competition in the hotel industry is really tough and architects endowed with futurist imagination can indulge in designing hotels that set Guinness World Records. Some of these hotels are located in the United Arab Emirates, and the city of Dubai, situated in the south-eastern part of the Arabian Peninsula on the shore of the Persian Gulf, is worldfamous for its hotels erected on land as well as on water [16]. Its most recent architectural achievement is Burj Khalifa - the Khalifa Tower - currently the world's tallest man-made structure, officially opened on 5 January 2011. The building is 828 meters high and has 206 floors, of which 162 are available to the public. The Tower beats more than just the height record: the $124^{\text {th }}$ floor has the highest outdoor observation deck, the $122^{\text {nd }}$ floor has the highest restaurant, and the $76^{\text {th }}$ floor - the world's highest swimming pool. In addition, there are 57 elevators in the building, each of which can exceed the speed of 60 kilometers per hour. The magnificent structure has been noticed by the fashion designer Giorgio Armani, whose first hotel bearing his name, launched in March 2011 and occupying Burj Khalifa's nine lowermost floors, has become the Tower's greatest jewel. The Armani Residences, his next project and part of the Armani Hotel, is going to be lodged on seven floors beneath ground level. Another of Dubai's most spectacular structures is the offshore hotel Burj Al Arab, one of the most interesting and luxurious buildings on Earth. Shaped as a gigantic sail and located on an artificial island 280 meters off the beach, it is easily recognizable by these two distinctive features.

The United Arab Emirates have many more exceptional buildings, of which perhaps the most singular is the Hydropolis Underwater Hotel and Resort, located 20 meters beneath the surface of the Persian Gulf. This world's premiere underwater hotel provides a wide range of services at any time of day or night. It houses underwater museums, a research institute, more than 200 exclusive apartments, and a number of high-class restaurants. Since the Hotel's structure must be strong enough to resist the pressure of sea water, all of its window panes are made of highly durable plexiglass, and a great deal of concrete and steel has been used to reinforce its shell.

The Emirates Palace Hotel is just one more that deserves special attention. It is situated in Abu Dhabi, the capital city of the United Arab Emirates. Its first visitors checked in in February 2005, and since then the hotel has earned the reputation of a genuine palace - the most exquisite among hotels of the world. All furnishings have been specially designed or customized for the hotel. The most luxurious suites are packed with gold and padded with Persian carpets. The hotel hosts more than a dozen restaurants, including an underwater one. Observation decks, hanging gardens, fountains, cascades, and a multi-level aquarium containing a complete coral reef, are all there for one to feast one's eyes upon. You can enjoy all these for an exorbitant 35,000 US dollars per night.

\section{What the future hotels will be like}

Hotels of the future will be just as diverse, which appears consistent with further polarization of societies [14]. The following types of hotels are envisaged:

- hotels for people who are "fed up with luxury". 
- hotels for individualists,

- business hotels and convention centers,

- $\quad$ spa and resort hotels providing health care services,

- luxury hotels,

- budget hotels.

The German architect and hotel designer Jurgen Meyer argues that a rich variety of accommodation styles will go hand in hand with increasing specialization. Hotels will be targeted at tourist groups at specific age and with specific interests. It is believed that a trend will encourage the construction of "lifestyle hotels" characterized by homey atmosphere. Most hotels will certainly be equipped with a growing number of modern technical devices (which is enforced by the dynamic development of technology), new information technology solutions, and sophisticated gadgets. Interior styles will reflect the progress in technology. Terry Addison from London's Arniston Design thinks that hotels are going to have an increasingly attractive design. Utility will prevail over luxury. The so called "feature hotels", imitating e.g. castles, historic buildings, or emulating specific local cultures, will become fashionable. On the other hand, some hotels will be made of modules, resembling capsules or plain containers, which can be set up anywhere in the world. Hotel Everand is a perfect example [15]. The demographic trend of increasing average lifespan suggests that accommodation will need to have functionalities to meet the requirements of elderly people.

Further growth of space tourism, health tourism and ecological tourism is to be expected. A lot of attention will be given to biodegradability, closed water circulation systems, and rational use of water and cleaning agents. It is predicted that the walls of hotel rooms will be covered by lush vegetation which, well lit and watered, will take care of filtering the air.

Hotel furniture are supposed to be more versatile, lighter, movable and portable, easy to remove in case they have to be replaced in order to satisfy a guest's individual taste. Nanotechnology will be applied in toilets and bathrooms - the walls will be coated with antibacterial tiles, and the bathtub will adjust to individual body shapes [10].

As a matter of fact, this futurist vision of the hotel industry is almost a reality already. The robust development of technology will stimulate innovation, ensuring the industry's further quantitative and qualitative growth.

\section{Future trends and forecasts in tourism}

Just recently, the UNWTO published a report entitled "Tourism towards 2030 / Global Overview", which delivers estimates of international tourist travels around the world until 2030 [22]. The authors argue that the next two decades will be of sustained growth for the tourism sector, as international tourist arrivals are set to increase by an average 43 million a year between 2010 and 2030. At the projected pace of growth, we will surpass the 1 billion mark by 2012, and by 2030, the number is anticipated to reach 1.8 billion. Today, the tourist industry contributes $5 \%$ of the world's GDP, and one in 12 jobs globally. At the same time, it is a major export sector for many countries, both in the developing and developed world. UNWTO forecasts are based on the International Monetary Fund projections of $4 \%$ annual global GDP growth [20] (the real GDP growth for specific regions of the world is projected at $+5.7 \%$ in Asia, $+4.8 \%$ in Africa, $+4.3 \%$ in the Near 
East, and $+2.6 \%$ in Europe and the Americas). The number of international tourist arrivals worldwide is forecast to increase by 3.3\% a year over the period 2010-2030, compared to an average of $3.9 \%$ a year between 1995 and 2010. It is assumed that, over time, the rate of growth is going to slow down gradually, from $3.8 \%$ in 2011 to $2.5 \%$ in 2030. Europe will continue to lead in inbound tourism per 100 of population, yet its share in the global market will drop from $51 \%$ in 2010 to $41 \%$ in 2030 . It should be noted that this declining trend has been observed since 1980, when Europe's share of international tourist equaled $61 \%$. It is also projected that the 2010-2030 growth rate for inbound international travel will reach $+3.1 \%$ for Eastern and Central Europe, much higher than the $+1.8 \%$ for Northern Europe. The UNWTO estimates that Europe will be visited by a total of $744 \mathrm{~m}$ tourists in 2030, of which $82 \mathrm{~m}$ tourists will visit Northern Europe, $222 \mathrm{~m}$ people will arrive in Western Europe, $176 \mathrm{~m}$ - in Central and Eastern Europe, and 264m - in Southern Europe.

Based on research and analyses conducted in the first decade of the 21 st century, the UNWTO has distinguished the following twelve megatrends in world tourism, making up a panorama of tourism in 2020 [4]:

1. globalization vs. localization;

2. electronic technology will become omnipresent in searching tourist destinations;

3. traveling by fast routes and fast means of transport - the primary emphasis falling on facilitating and accelerating the travel process;

4. customers will choose locations via such technologies as online maps and online hotel database search, while agents and other intermediaries will offer educed rates for last-minute purchases;

5. there will be further polarization of customers' preferences along the divide into those who want maximum comfort and those who seek adventure;

6. the shrinking of the tourist world - more tourists will select locations off the beaten track;

7. an era of Earth-centered space travel will dawn;

8. the development of a market for products targeted at customers oriented on (a combination of) three elements: entertainment, sightseeing and education;

9. greater concern for the image of tourist spots as a precondition for diversification and increased tourist attractiveness;

10. everyone is going to woo Asian tourists;

11. the growing impact of tourists-led campaigns for sustainable development of tourism and ethics in tourism;

12. conflict between the customers' increasing social and environmental awareness and their growing willingness to travel.

\section{LIST OF REFERENCES}

1. Alejziak W., T. Marciniec: Międzynarodowe organizacje turystyczne. Kraków: ALBIS, 2003.

2. Alejziak $W .:$ "Działalność liderów przemysłu turystycznego w świetle aktualnych tendencji występujących na rynku. Studium przypadku First Choice i Forte". Folia Turistica, No. 9/2000. Kraków: Instytut Turystyki AWF, 2000.

3. Briggs S.: Marketing $w$ turystyce. Warszawa: PWE, 2003. 
4. Burzyński T., D. Dryglas (eds), Prognozy rozwoju oraz oddziaływania turystyki na rynek pracy oraz modernizację przedsiębiorstw $w$ województwie ślaskim. Kraków: Instytut Turystyki w Krakowie Sp. z o.o., 2010.

5. Castenow: Nowy Marketing w praktyce. Warszawa: PWE, 1996.

6. Celente G.: Trendy 2000. Warszawa: Philip Wilson, 1999.

7. Gawrońska M.: "Kierunek Północ". Newsweek (Polish edition) of 27 June 2010.

8. Grzeszak A.: Przemyst..., op. cit.

9. http://en.wikipedia.org/wiki/Ice_hotel

10. http://en.wikipedia.org/wiki/Nanotechnology

11. http://wiadomosci.gazeta.pl/wiadomosci/1,114881,10546452,Virgin_Galactic_pierwsi_ kosmiczni_turysci_poleca.html

12. http://wiadomosci.gazeta.pl/wiadomosci/1,114881,9646588,Mordercze_tornado_w_USA. $\mathrm{html}$

13. http://www.booking.com/hotel/pl/queen-boutique-krakow.pl.html

14. http://www.e-hotelarz.pl/mht/?p=2244

15. http://www.everland.ch

16. http://www.podroze.pl/wasze-wyprawy/relacje/relacja/ekskluzywne-hotele-dubaju,3540/

17.http://www.tur-info.pl/p/ak_id,14710,,wiezienie,areszt,hotel,budowa,modernizacja, remont,hotel_liberty,beacon_hill.html

18. Kwiatkowski K.: "Marzyciele z Antarktydy". Newseek (Polish edition) of 24 January 2010.

19. Święcicka K.: "Hotel pod designer". Newsweek (Polish edition) of 24 January 2007.

20. The IMF's forecasts and the long-run tables of GDP compiled by the late Angus Maddison. Sources: IMF World Economic Outlook 2012 [http://www.imf.org/external/pubs/ft/ weo/2012/02/index.htm]; The Super-Cycle Report, Standard Chartered Research Bank 2010.

21. Toffler A.: Future Shock. New York: Random House, 1970.

22. Tourism Towards 2030 / Global Overview. World Tourism Organization (UNWTO), Madrid 2011.

Стаття: надійшла до редколегії 06.06.2012

прийнята до друку 15.06.2012 


\title{
РОЛЬ ТРЕНДІВ У ВИЗНАЧЕННІ НАПРЯМКІВ РОЗВИТКУ ТУРИЗМУ ТА ГОТЕЛЯРСТВА У ХХІ СТОЛІТТІ
}

\author{
Я. Рушковський *, К. Котра ** \\ * Сілезька школа економіки \\ Відділ маркетингу \\ ** Банківська шккола в Познані \\ Познань, Польща
}

Нові тенденції в готельному бізнесі і туристичному ринку обумовлені економічними факторами, а також похідною геополітичних змін, які нещодавно мали місце в світі. Це, зокрема найбільший туристичний ринок, яким є Свропа, де відбулися значні події (в тому числі крах тоталітарної радянської системи, демократизація суспільства в колишніх соціалістичних країнах, зростання Європейського Союзу і т.д.). Ефектом цих змін $\epsilon$ глобалізація поставок туризму і попиту, на основі інтеграції в міжнародну торгівлю нових туристичних країн й цілих географічних регіонів. Метою даної статті є показати, як вони використовуються для визначення тенденцій у розвитку туризму і гостинності в цьому столітті.

Ключові слова: туризм та готельний ринок, нові розробки, тенденції і напрямки розвитку світового туризму і відпочинку, промисловості та UNWTO до 2020 року 


\title{
РОЛЬ ТРЕНДОВ В ОПРЕДЕЛЕНИИ НАПРАВЛЕНИЙ РАЗВИТИЯ ТУРИЗМА И ОТЕЛЬНОГО БИЗНЕСА В ХХІ ВЕКЕ
}

\author{
Я. Рушковский *, К. Котра ** \\ * Силезская школа экономики \\ Отдел маркетинга \\ ** Банковская школа в Познани \\ Познань, Польша
}

\begin{abstract}
Новые тенденции в гостиничном бизнесе и туристическом рынке обусловлены экономическими факторами, а также производной геополитических изменений, которые недавно имели место в мире. Это, в частности крупнейший туристический рынок, которым является Европа, где произошли значительные события (в том числе крах тоталитарной советской системы, демократизация общества в бывших социалистических странах, рост Европейского Союза и т.д.). Эффектом этих изменений является глобализация поставок туризма и спроса, на основе интеграции в международную торговлю новых туристических стран и целых географических регионов. Целью данной статьи является показать, как они используются для определения тенденций в развитии туризма и в этом веке.
\end{abstract}

Ключевые слова: туризм и гостиничный рынок, новые разработки, тенденции и направления развития мирового туризма и отдыха, промышленности и UNWTO до 2020 года 